\title{
Stock Market Development and Economic Growth: Empirical Evidence From an Institutional Impaired Economy
}

\author{
Maku Affor Owen ${ }^{1}$ \\ ${ }^{1}$ Delta State University, Abraka, Nigeria \\ Correspondence: Maku Affor Owen, Delta State University, Abraka, Nigeria. E-mail: makuowen@gmail.com
}

Received: June 11, 2020

Accepted: September 9, 2020

Online Published: October 5, 2020

doi:10.5430/ijfr.v11n5p496

URL: https://doi.org/10.5430/ijfr.v11n5p496

\begin{abstract}
The research investigated the relationship linking stock market development and economic growth from 1985 to 2018 . In measuring growth, Gross domestic product (GDP) was adopted, while stock market was surrogated by turnover ratio, market-capitalization, and value of share- traded, sourced from the Central Bank of Nigeria (CBN) and the Security and Exchange Commission Database. The inclusion of money supply (M3) captured innovation (financial) in the monetary sector. In investigating the aforementioned relationship, the ARDL Bound test methodology was adopted. Empirical results from the investigation confirm the existence of a long-run relationship between stock market development and growth. Similarly, there was a positive relationship between indices of stock market development and growth, albeit statistically insignificant. The study concluded that financial institutions should concentrate on financial innovation in other dimensions in other to boost stock market performance that will result in sustainable growth.
\end{abstract}

Keywords: financial market, economic growth, stock market, money supply, financial innovation

JEL: N21, O40, D53, E51, O53

\section{Introduction}

As Africa's financial markets tend towards a higher degree of complexity, the stock markets' relevance cannot be overemphasized. Shittu (2012) posits that stock markets' contribute to growth through certain channels such as creation of liquidity, mobilization of savings for private and public sectors, risk diversification, and improved dissemination of information. Through the delivery of these services, the advancement of economic growth can be enhanced. In most developing economies, the emergence and growth of stock markets have reliably increased over time. Amid stock market size and illiquidity, its continuous turn of events and existence may have an expanding impact for growth. Pardy (1992) argued that even in LDCs, capital markets/institutions can mobilize savings (domestic) and distribute funds more efficiently. In this way, the stock-market can play its principal role in stimulating LDCs growth by attracting and redirecting investment to where it is needed.

Several studies relating to the Nigerian economy have constantly and consistently appraised the responsibility of the stock market on economic growth. A number of studies have observed the potential of the Nigerian stock market to stimulate growth (Olofin \& Afangideh, (2008); Ogunmuyiwa, 2010 and Ezeoha, Ogamba \& Onyiuke, (2009)). These studies have found positive effects, flowing from the stock market to economic growth. Odhiambo (2009) argues that the development of the stock market Granger-causes economic growth while Ndako (2009) conversely asserts empirically that economic growth granger causes stock market development, with similar evidences from time series data adopted above. In addition, recent studies including (Osakwe \& Ananwude, (2017); Okonkwo et. al, (2015) and Adigwe et. al, (2015); Carpenter \& Whitelaw, (2017); Babjide et. al, (2016); Brown \& Nyeche, (2016); Pan \& Mishra, 2018) empirically confirmed that the development of the stock market positive contribution to economic growth. On the basis of the assumption, this study critically analyzed the relationship between stock market development and economic growth in Nigeria. This research paper specifically assesses the stability, depth and efficiency through its interplay with financial innovation on the growth of the Nigerian economy.

The remainder of this paper is subdivided into four different sections. Section two covers relevant analytical and theoretical research, section three discusses the methodology adopted; section four focuses on presenting the results and discussion of findings, while section five provides relevant policy recommendations. 


\section{Literature Review}

The relevance of the contribution of the financial system in improving and promoting development cannot be overemphasized. The financial sector comprises the Central Bank, commercial banks, Investment companies, brokerage firms, discount houses, and the stock exchange, to name just a few. These institutions trade in financial instruments that include stocks, derivatives, foreign and domestic currencies, shares, and so on, and mobilize funds from surplus to units of deficit in the same process. This helps to boost investment and increase production for businesses and corporations, thereby accelerating growth. The debate on the functioning of the financial system began with Schumpeter (1912), who argued that banks operate in a well-functioning financial system to stimulate economic growth by stimulating technological innovation by identifying and financing entrepreneurs with the best opportunity to launch innovative products, in addition to the production process. Levine (1991) was of the opinion that a well-developed stock market possesses the capacity to absorb liquidity shocks and productivity shocks of businesses. In the same vein, Levine \& Zervos (1998) and Khan \& Senhadji (2000) have pointed out that the establishment of the stock market has made significant contribution to the growth of financial institutions in emerging-market economies. The expansion of the financial sector (including the stock market) is therefore assumed to make substantial contribution to growth.

\subsection{Stock Market Performance and the Nigerian Economy}

Table 1 and 2 shows key stock market growth metrics (stock market size, depth, and market stability) for the period 1985-2018. Prior to onset of the global financial crisis and financial sector reforms in 2005, the Nigerian stock market was well adjusted, as market indices (market capitalization, market turnover, value of shares traded and the all-share index) rose from low to historically high levels. For instance, market capitalization increased from N5bn in 1985 to N18.3bn in 1990, and further increased to N165.10bn in 1995, representing an increase of about 13.56 percent as a share-of-GDP. In 2000 and 2005, market capitalization was set at N379.71bn and N2, 066.80bn, representing an increase of 51 percent as a share of GDP. This period marks the entrant into the era of post consolidation. The rapid development of the stock market, however, was primarily the result of stock market trading which resulted in just few stocks, accounting for a substantial part of overall market capitalization. There are unsmilingly informational and disclosure deficiencies for other securities, as well as stern flaws in the lucidity of transactions in the market, away from these active-traded shares. Similarly, market turnover resumed a growing trend, increasing from 2000 to 2005 to 6 percent to 10.1 percent. The all-share index also performed well, rising from 117points in 1985 to 3,815 points in 1995 and further to 6,701 points in 2000 . The all-share index peaked at 50,424points in 2008 and was steadily decreasing to 37,186 points in 2018. Regrettably, as market metrics deteriorated quickly, the boom experienced in the market was upturned. For example, market capitalization in 2018 currently stands at N16,185.7billion, indicating a decreasing GDP ratio of 7.36 percent, while market turnover reported a decline of around 7 percent in 2018 compared to 10.10 percent in 2010 (CBN Annual Report, 2019).

Table 1. Indicators of stock market development for Nigeria

\begin{tabular}{|c|c|c|c|c|c|}
\hline & Ratio to GDP (percent) & & & & \\
\hline Year & Stock market turnover & $\begin{array}{l}\text { Stock market to total } \\
\text { value-traded }\end{array}$ & $\begin{array}{l}\text { Stock } \\
\text { capitalization }\end{array}$ & market & $\begin{array}{l}\text { Stock market capitalization } \\
\text { (World) }\end{array}$ \\
\hline 1995 & 1.07 & 0.18 & 17.65 & & 66.04 \\
\hline 2005 & 8.78 & 1.10 & 12.62 & & 92.52 \\
\hline 2010 & 10.10 & 1.40 & 13.91 & & 88.48 \\
\hline 2015 & 8.17 & 0.82 & 10.10 & & 94.96 \\
\hline 2016 & 5.36 & 0.37 & 7.36 & & 97.46 \\
\hline 2017 & 5.87 & 0.58 & 9.90 & & 111.83 \\
\hline 2018 & 8.20 & 0.65 & 7.93 & & 92.92 \\
\hline
\end{tabular}

Source: Global Financial Development Indicators, World Bank 


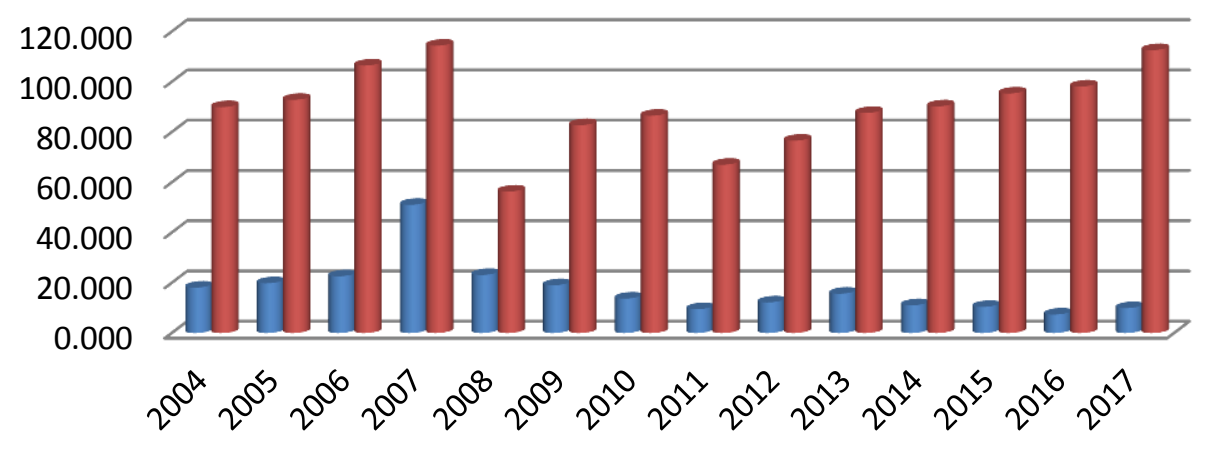

- Stock market capitalization to GDP (\%), Nigeria

- Stock market capitalization to GDP (\%), World

Figure 1. Nigeria's market capitalization ratio to World's market capitalization

Source: World Development Report, 2019

Table 2. Stock market development indicators for Nigeria (1985-2018)

\begin{tabular}{|c|c|c|c|c|}
\hline Year & $\begin{array}{l}\text { Market Capitalization } \\
\left(\mathbb{N}^{\prime} \text { Billion) }\right.\end{array}$ & All Share Index & $\begin{array}{l}\text { Turnover } \\
\text { Ratio (\%) }\end{array}$ & $\begin{array}{l}\text { Value of stocks } \\
\text { traded ( } \mathbb{\$}^{\prime} \text { Billion) }\end{array}$ \\
\hline 1985 & 5.075 & 117.283 & 0.5 & 0.316 \\
\hline 1990 & 18.334 & 423.658 & 0.7 & 0.225 \\
\hline 1995 & 165.099 & 3815.117 & 1.0 & 1.838 \\
\hline 2000 & 379.713 & 6701.175 & 6.0 & 28.153 \\
\hline 2005 & 2066.798 & 22876.717 & 10.1 & 262.935 \\
\hline 2010 & 6493.303 & 24775.512 & 10.1 & 799.911 \\
\hline 2015 & 10521.630 & 30867.195 & 9.7 & 978.047 \\
\hline 2016 & 9151.608 & 26624.077 & 6.2 & 620.018 \\
\hline 2017 & 11150.788 & 32161.113 & 9.3 & 1078.492 \\
\hline 2018 & 13499.618 & 37186.112 & 7.0 & $1,284.976$ \\
\hline
\end{tabular}

Source: NSE and CBN

Pagano (1993) argued that the stock-market contributes to the mobilization of domestic savings by strengthening the array of financial instruments available to savers in diversifying their portfolios, thereby providing a significant source of investment capital at a relatively low cost. A well-functioning and liquid stock market that provides investment opportunities to diversify unsystematic risks can improve capital's marginal productivity. Taking a retrospect at the World Federation of Exchanges in Paris, it is shown that overall global stock market capitalization, rose from US\$40.4 in 2005 to US\$50.9 trillion in 2010 (World Bank, 2019). As indicated in figure 1, the overall world stock market capitalization saw a steady rise per year from 92.52 percent in 2005 to 111.83 percent in 2017 and decreased to 92.92 percent in 2018 in terms of its share-of-GDP in terms of its share in GDP. Total global stock market capitalization, which in 1995 amounted to US\$ 66.04 trillion; increased to US\$111.83 trillion in 2017, nearly double the rise over seventeen (17) years. By comparison, stock market capitalization in Nigeria is experiencing an increasing trend. Successive periods (2016-2018) for market capitalization and market turnover ratio experienced undulating patterns which signifies poor performance underdevelopment of the stock market. The rapid development of global stock indicators (that is, market capitalization) has attracted serious attention of policymakers; thus focusing on the reasons for the under performance of the stock market in developing countries around the world over the last few decades, giving room to explore other dimensions that will result in the effective development the stock market and growth of developing economies (Deb \& Mukherjee, 2008) 


\subsection{Empirical Review}

Studies have produced mixed results with respect to country specific and cross-country research. Studies including Ikikii \& Nzomoi (2013), Bernard and Austin (2012), Ojo \& Adeusi (2012), Edame \& Okoro (2013), Kolapo \& Adaramola (2012), Afolabi (2015), Wang \& Ajit (2013), Okoye \& Nwisienyi (2013), Jibril et. al (2015), Echekoba, Ezu \& Egbunike (2013), Haque (2013), Fynn (2012), Sinha, Joshi, Venkartaraman, Padmanabhna \& Ravi (2015), Ologunwa \& Sadibo (2016), Odo, Anoke, Onyeisi \& Chukwu (2017), Karim \& Chaudhary (2017) either found that the development of stock markets had a positive impact on economic growth or had no significant effect on growth.

Table 3. Summary of relevant literature

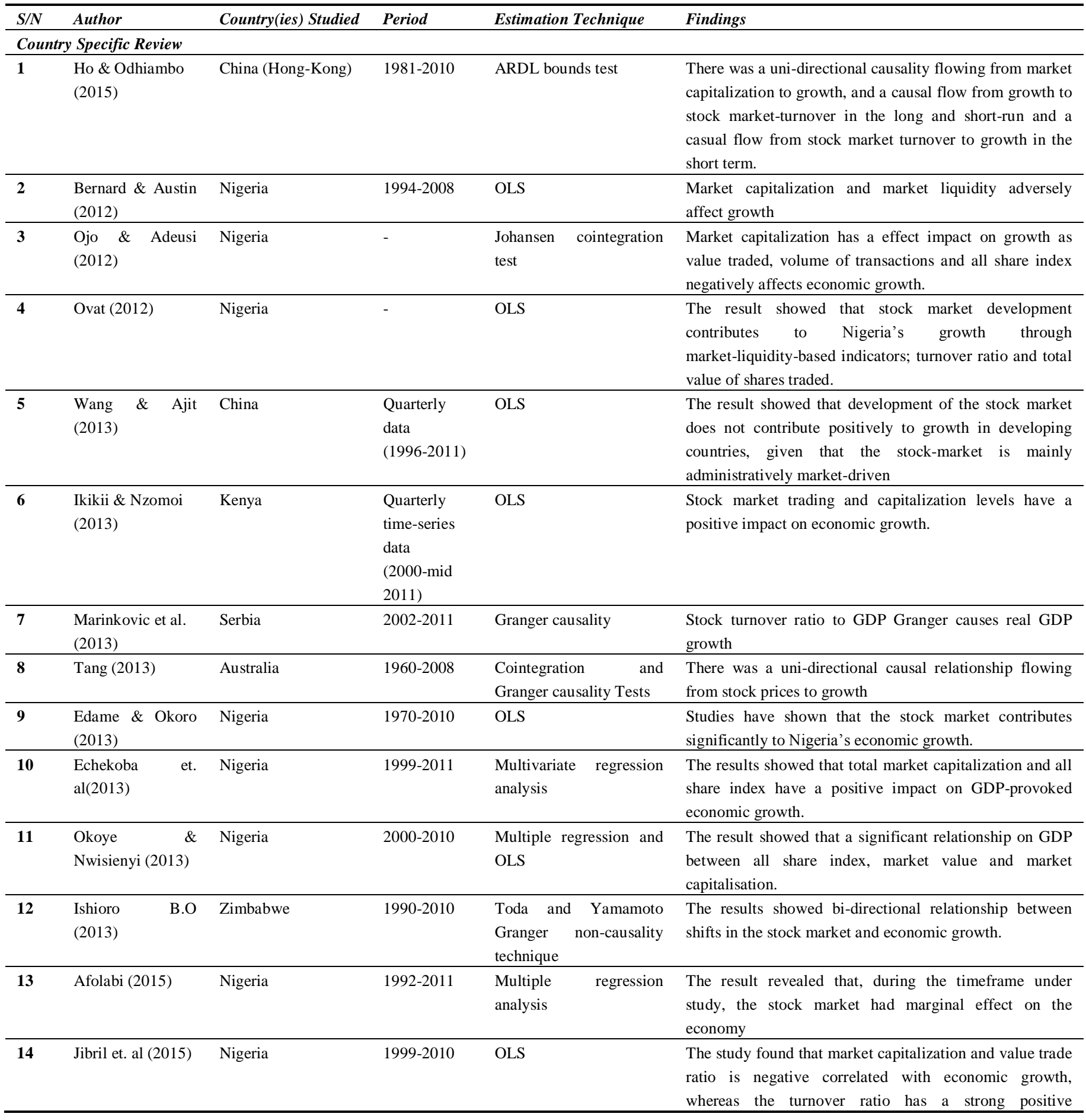




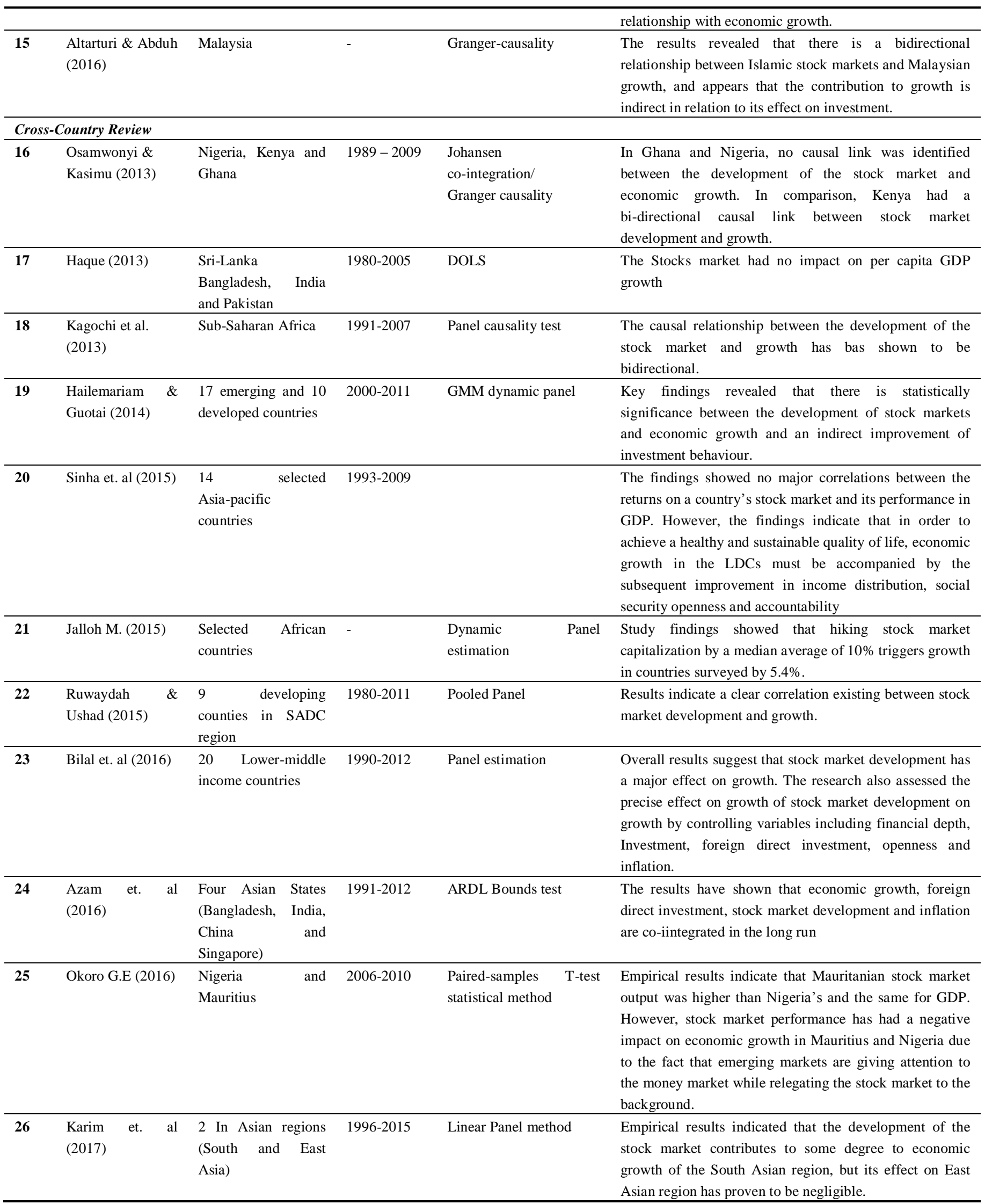

Source: Compiled by Author 


\section{Methodology}

The study adopts the ARDL model fundamentally centered on the following premise. First, regardless of the sample size, the ARDL model is advanced (Ghatak \& Siddiki, 2001). Secondly, particularly when the variables are integrated of different order (that is integrated at order zero or one), the method is further suitable. Third, modelling ARDL with the appropriate lags is standard for both the indigeneity problem and serial correlation, and fourth, the model can estimate the short and long-run relationship, thus providing unbiased estimates (Pesaran et. al, 2001). So, it is possible to express a simplified ARDL model as;

$$
\Delta y_{t}=\beta_{1}+\delta_{1} y_{t-1}+\delta_{2} x_{t-1}+\delta_{3} z_{t-1}+\eta_{1} \sum_{i=1}^{n} \Delta y_{t-1}+\eta_{2} \sum_{i=1}^{n} \Delta x_{t-1}+\eta_{3} \sum_{i=1}^{n} \Delta z_{t-1}+\mu_{t}
$$

Where, the long-run coefficients are $\left(\delta_{1}, \delta_{2}, \delta_{3}\right)$ whose sum of which corresponds to the ECM and, $\eta_{1}, \eta_{2}$,

$\eta_{3}$ are the short-run coefficients. The generalized ARDL model for investigating the effect on growth of the stock market is specified as follows;

$$
\begin{aligned}
& \Delta \ln (Y)_{t}=\alpha_{0}+\beta_{1} \Delta \ln (M C A P)_{t-1}+\beta_{2} \Delta \ln (\text { GFCF })_{t-1}+\beta_{3} \Delta \ln (M 3)_{t-1}+\beta_{4} \Delta \ln (Y)_{t-1} \\
& +\beta_{5} \Delta \ln (\text { TURNOVER })_{t-1}+\beta_{6} \Delta \ln (\text { VALTRD })_{t-1}+\phi_{7} \log (\text { MCAP })_{t}+\phi_{8} \log (\text { GFCF })_{t} \\
& +\phi_{9} \log (\text { M3 })_{t}+\phi_{10} \log (\text { TURNOVER })_{t}+\phi_{11} \log (\text { VALTRD })_{t}+\mu_{t}
\end{aligned}
$$

where $\mu_{t}$ the stochastic term, $t-1$ is the lagged period, $\Delta$ designates differencing of variables and $\phi_{7}-\phi_{11}$ are long run coefficients.

The unrestricted ECM is formulated as part of the ARDL approach to define the long run co-integration, taking into account each variables to estimate the best-fit model which is shown in the matrix below;

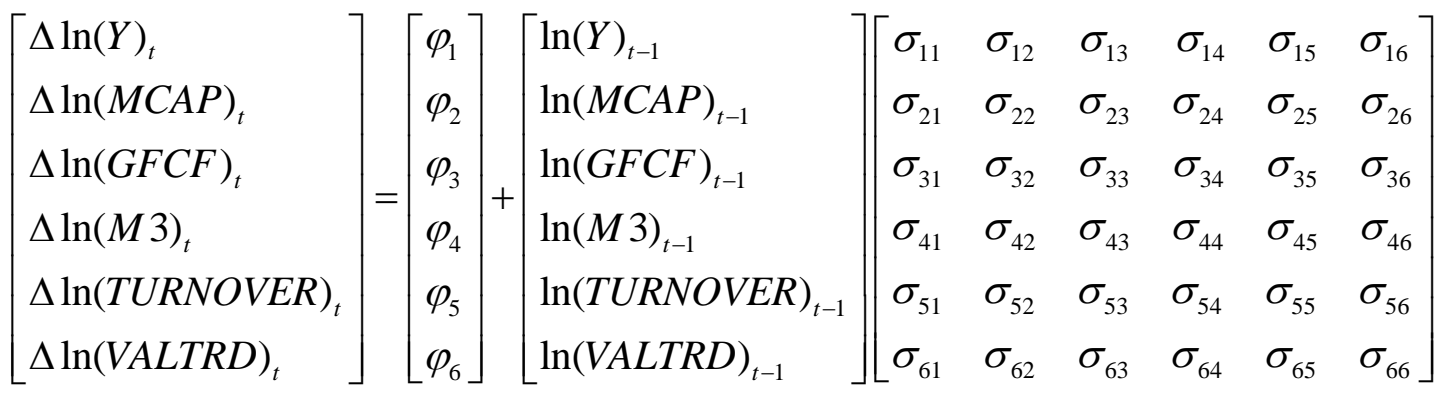

$$
\begin{aligned}
& +\sum_{h=1}^{q}\left[\begin{array}{llllll}
v_{11 h} & v_{12 h} & v_{13 h} & v_{14 h} & v_{15 h} & v_{16 h} \\
v_{21 h} & v_{22 h} & v_{23 h} & v_{24 h} & v_{25 h} & v_{26 h} \\
v_{31 h} & v_{32 h} & v_{33 h} & v_{34 h} & v_{35 h} & v_{36 h} \\
v_{41 h} & v_{42 h} & v_{43 h} & v_{44 h} & v_{45 h} & v_{46 h} \\
v_{51 h} & v_{52 h} & v_{53 h} & v_{54 h} & v_{55 h} & v_{56 h} \\
v_{61 h} & v_{62 h} & v_{63 h} & v_{64 h} & v_{65 h} & v_{66 h}
\end{array}\right]\left[\begin{array}{l}
\Delta \ln (Y)_{t-h} \\
\Delta \ln (M C A P)_{t-h} \\
\Delta \ln (G F C F)_{t-h} \\
\Delta \ln (M 3)_{t-h} \\
\Delta \ln (T U R N O V E R)_{t-h} \\
\Delta \ln (V A L T R D)_{t-h}
\end{array}\right]+\left[\begin{array}{l}
\mu_{1 t} \\
\mu_{2 t} \\
\mu_{3 t} \\
\mu_{4 t} \\
\mu_{5 t} \\
\mu_{6 t}
\end{array}\right]
\end{aligned}
$$

where $\varphi_{1}-\varphi_{6}$ represents constant terms, $\sigma_{11}-\sigma_{66}$ represents long run coefficients, $v_{11}-v_{66}$ represents short run coefficients, and $\Delta$ for the first difference. The bound test is conducted using the F-tests to evaluate the long-run relationship between the variables. In equation 3, the null hypothesis of no-cointegration is; 


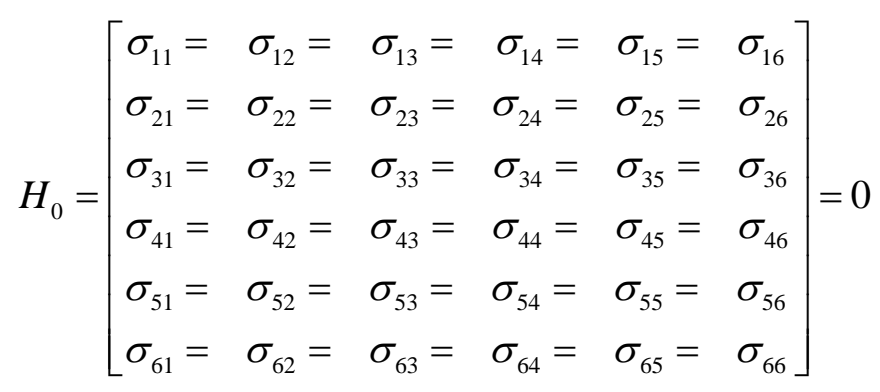

As against the alternative hypothesis is;

$$
H_{1}=\left[\begin{array}{llllll}
\sigma_{11} \neq & \sigma_{12} \neq & \sigma_{13} \neq & \sigma_{14} \neq & \sigma_{15} \neq & \sigma_{16} \\
\sigma_{21} \neq & \sigma_{22} \neq & \sigma_{23} \neq & \sigma_{24} \neq & \sigma_{25} \neq & \sigma_{26} \\
\sigma_{31} \neq & \sigma_{32} \neq & \sigma_{33} \neq & \sigma_{34} \neq & \sigma_{35} \neq & \sigma_{36} \\
\sigma_{41} \neq & \sigma_{42} \neq & \sigma_{43} \neq & \sigma_{44} \neq & \sigma_{45} \neq & \sigma_{46} \\
\sigma_{51} \neq & \sigma_{52} \neq & \sigma_{53} \neq & \sigma_{54} \neq & \sigma_{55} \neq & \sigma_{56} \\
\sigma_{61} \neq & \sigma_{62} \neq & \sigma_{63} \neq & \sigma_{64} \neq & \sigma_{65} \neq & \sigma_{66}
\end{array}\right]=0
$$

According toPesaran et. al (2001), the criteria for the decision making are as follows;

i. The presence of cointegration is verified if $F_{h}>$ upper bound critical value

ii. If $F_{h}<$ upper-bound critical value, it confirms that the variables are not cointegrated

iii. If $F_{h} \leq / \geq$ upper/lower bound critical value, then the cointegration decision is inconclusive

The long run equilibrium is thus modelled as follows;

$$
\begin{aligned}
& \ln Y_{t}=\omega_{0}+\sum_{k=1}^{m} \alpha_{k} \ln (Y)_{t-k}+\sum_{k=0}^{n} \beta_{k} \ln (M C A P)_{t-k}+\sum_{k=0}^{p} v_{k} \ln (G F C F)_{t-k}+\sum_{k=0}^{q} \pi_{k} \ln (M 3)_{t-k} \\
& +\sum_{k=0}^{r} \chi_{k} \ln (\text { TURNOVER })_{t-k}+\sum_{k=0}^{r} \chi_{k} \ln (\text { VALTRD })_{t-k}+\varepsilon_{t}
\end{aligned}
$$

The short-run elasticities can be generated by formulating the following error correction;

$$
\begin{aligned}
& \Delta(\ln Y)_{t}=\omega_{0}+\sum_{k=1}^{m} \alpha_{k} \Delta \ln (Y)_{t-k}+\sum_{k=0}^{n} \beta_{k} \Delta \ln (M C A P)_{t-k}+\sum_{k=0}^{p} \nu_{k} \Delta \ln (G F C F)_{t-k}+\sum_{k=0}^{q} \pi_{k} \Delta \ln (M 3)_{t-k} \\
& +\sum_{k=0}^{r} \chi_{k} \ln (\text { TURNOVER })_{t-k}+\sum_{k=0}^{r} \chi_{k} \ln (\text { VALTRD })_{t-k}+\varsigma E C T_{t-1}+\psi_{t}
\end{aligned}
$$

Table 4. Description and nomenclature of variables

\begin{tabular}{lll}
\hline Variable & Definition & Expected sign \\
\hline Dependent variables & & \\
\hline $\begin{array}{l}\text { Economic growth } \\
\text { (EGWTH) }\end{array}$ & $\begin{array}{l}\text { An inflation-adjusted indicator reflecting the value of all goods and services } \\
\text { produced following Ishioro (2013); Hasan \& Barau (2015) by an economy } \\
\text { measured in constant price. }\end{array}$ & \\
\hline Independent variable & & Positive \\
\hline $\begin{array}{l}\text { Gross fixed capital } \\
\text { formation }(\text { GFCF })\end{array}$ & Measures the net increase in fixed capital as a percentage of GDP & \\
\hline Money supply $(\mathbf{M B})$ & $\begin{array}{l}\text { A measure of money supply which includes M2 as well as large time deposits, } \\
\text { retail money market funds, short-term repurchase agreements and high liquid }\end{array}$ & \\
\hline
\end{tabular}


assets, emphasizing money more as a store-of-value than as a means of exchange, calculated as a percentage of GDP

Market capitalization According to Nyasha \& Odhiambo $(2015,2016)$, the aggregate value of the Positive (MCAP) firm based on the current share price and the total number of outstanding stocks that serves as an instrument enabling the investor assess the returns and risk in the share, measured as percent ageof GDP.

Turnover ratio $\quad$ This ratio represents the proportion of stocks that changes in a fiscal year. Positive This is used to evaluate the company's efficiency on how it uses its assets to generate revenue, measured in percentage ponts, following Nyasha \& Odhiambo $(2015,2016)$

Value of stock traded According to Nyasha \& Odhiambo $(2015,2016)$, this refers to the total Positive (VALTRD) number of shares-traded, both domestic and foreign, multiplied by their respective matching prices

Source: Compiled by Author

\section{Analysis of Data and Discussion of Results}

This section began with the descriptive statistics and correlation properties of variables used. On the premise of the data obtained for Nigeria, the mean for economic growth for the period is approximately 17.31 percent, with maximum and minimum value (18.061) and (16.648) percent respectively. The mean values for market capitalization, turn-over ratio and value of shares traded are (13.122 percent), (1.288 percent) and (9.817 percent), with their corresponding maximum and minimum values of (16.427 and 7.916 percent), (3,526 and -1.203 percent) and (14.680 and 2.631) percent respectively. The $p$-values of the Jarque-Bera indicate that all of the variables are normally distributed as seen in Table 5, Panel B.

Table 5. Summary statistics for period (1985-2018)

\begin{tabular}{|c|c|c|c|c|c|c|}
\hline & EGWTH & GFCF & M3 & MCAP & TURNOVER & VALTRD \\
\hline \multicolumn{7}{|c|}{ Panel-A: Descriptive statistics (level value) } \\
\hline Mean & 27126109 & 31.362 & 5757666 & 3770831 & 6.891 & 437477.8 \\
\hline Maximum & 28701907 & 54.948 & 25079721 & 13619906 & 34.000 & 2375619 \\
\hline Minimum & 16997518 & 14.168 & 22299.24 & 2743.100 & 0.300 & 13.900 \\
\hline Std. Dev. & 18640860 & 13.476 & 7753023 & 4691060 & 6.832 & 626633.6 \\
\hline Jarque-Bera & 4.099 & 2.751 & 7.862 & 5.077 & 62.212 & 18.477 \\
\hline Probability & 0.128 & 0.252 & 0.019 & 0.078 & 0.000 & 0.000 \\
\hline \multicolumn{7}{|c|}{ Panel- B: Descriptive statistics (natural log value) } \\
\hline Mean & 17.310 & 3.346 & 13.892 & 13.122 & 1.288 & 9.817 \\
\hline Maximum & 18.061 & 4.006 & 17.037 & 16.427 & 3.526 & 14.680 \\
\hline Minimum & 16.648 & 2.651 & 10.012 & 7.916 & -1.203 & 2.631 \\
\hline Std. Dev. & 0.491 & 0.464 & 2.333 & 2.870 & 1.345 & 4.155 \\
\hline Jarque-Bera & 3.386 & 3.058 & 2.648 & 3.155 & 3.415 & 3.720 \\
\hline Probability & 0.183 & 0.216 & 0.266 & 0.206 & 0.181 & 0.155 \\
\hline \multicolumn{7}{|c|}{ Panel C: Correlation Matrix } \\
\hline$E G W T H$ & 1 & & & & & \\
\hline GFCF & $0.911 * *$ & 1 & & & & \\
\hline M3 & $0.959^{* *}$ & $0.797 * *$ & 1 & & & \\
\hline MCAP & $0.950 * *$ & $0.849 * *$ & $0.924 * *$ & 1 & & \\
\hline TURNOVER & $0.519^{* *}$ & $0.679 * *$ & $0.366^{* *}$ & $0.534 * *$ & 1 & \\
\hline VALTRD & $0.725^{* *}$ & $0.715^{* *}$ & $0.660 * *$ & $0.828 * *$ & $0.838 * *$ & 1 \\
\hline
\end{tabular}

Source: Author's Computation using E-views 10

N.B: EGWTH = Economic Growth; GFCF = Gross Fixed Capital Formation; M3: Broad Money Supply; MCAP = Market Capitalization; TURNOVER $=$ Turnover ratio; VALTRD $=$ Value of shares traded; Std. Dev. $=$ Standard Deviation; ** signifies significant at 5\% level 
Table 6. Stationarity Test

\begin{tabular}{|c|c|c|c|c|c|}
\hline & \multicolumn{2}{|c|}{ At level } & \multicolumn{2}{|c|}{$I^{\text {st }}$ Difference } & \multirow[b]{2}{*}{ Decision } \\
\hline & $\overline{A D F(\text { prob.) }}$ & PP (prob.) & $A D F$ (prob.) & $\overline{P P}$ (prob.) & \\
\hline$E G W T H$ & $-3.861(0.025)^{* *}$ & $-3.796(0.029)^{* *}$ & - & - & $\mathrm{I}(0)$ \\
\hline$G F C F$ & $-3.194(0.102)$ & $-0.762(0.816)$ & $-6.687(0.000)^{* *}$ & $-10.009(0.000)^{* *}$ & $\mathrm{I}(1)$ \\
\hline M3 & $1.383(0.999)$ & $1.388(0.999)$ & $-4.946(0.001)^{* *}$ & $-4.960(0.001)^{* *}$ & $\mathrm{I}(1)$ \\
\hline MCAP & $-2.778(0.214)$ & $-2.778(0.214)$ & $-6.465(0.000)^{* *}$ & $-14.519(0.000)^{* *}$ & $\mathrm{I}(1)$ \\
\hline TURNOVER & $-2.627(0.271)$ & $-2.627(0.271)$ & $-5.511(0.000)^{* *}$ & $-7.631(0.000)^{* *}$ & $\mathrm{I}(1)$ \\
\hline VALTRD & $-2.038(0.269)$ & $-1.912(0.322$ & $-5.954(0.000)^{* *}$ & $-10.252(0.000)^{* *}$ & $\mathrm{I}(1)$ \\
\hline
\end{tabular}

Source: Author's Computation using E-views 10

N.B: ** signifies significant at $5 \%$ level

The stationarity test in Table 6 indicates mixed order of integration. Economic growth is stationary at level, I(0), whereas at first difference, other variables (capital formation, money supply, market capitalization, turnover ratio and value traded) are integrated at order one, I(1). A mixed order of integration allows the adoption of the ARDL bounds test, based on the aforementioned result, to capture the long-run cointegration among the variables, Pesaran et. al (2001).

Table 7. ARDL Bound test results [Long run Co-integration]

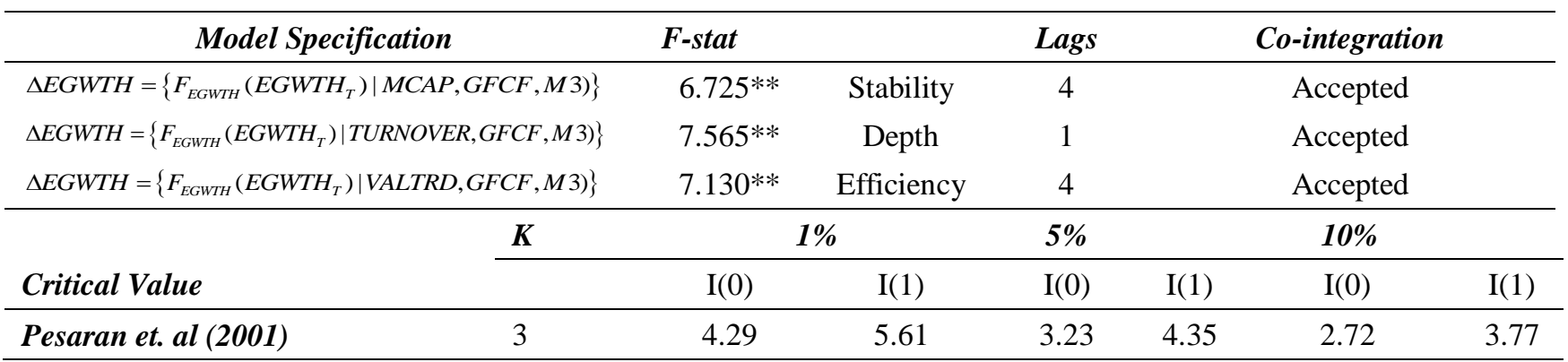

Source: Author's Computation using E-views 10; N.B: ** signifies significant at 5\% level; Lag length section criterion $=$ Akaike Information Criterion (AIC)

Three (3) ARDL bound test are executed from table 7, showing their respective computed F-statistics. Results indicate a long run relationship across all three models. This means that the no cointegration hypothesis against its alternative is dismissed at c.v (1\%, 5\% and 10\%). The computed F-statistic of 6.725 is higher than the upper bound critical value of 4.35 at $5 \%$, indicating a long-run relationship between market capitalization, gross fixed capital formation, money supply and growth. Therefore, the finding is replicated for the other two models which signifies the depth and efficiency of the interaction of the stock market with growth as revealed from their computed F-statistic values (7.565 and 7.130) respectively. Based on the results shown in table 7, it is evident that stock market development has a long run effect on growth in Nigeria. 
Table 8. Coefficient of long-run ARDL Model (period 1985-2018)

\begin{tabular}{|c|c|c|c|}
\hline & \multicolumn{3}{|c|}{ Stock-Market Development long run empirical assessment } \\
\hline & Equation 1 & Equation 2 & Equation 3 \\
\hline & $\operatorname{ARDL}(1,0,0,1)$ & $\operatorname{ARDL}(1,0,0,1)$ & $\operatorname{ARDL}(1,0,0,1)$ \\
\hline$\Delta \operatorname{lnEGWTH}_{\mathrm{t}-1}$ & $1.168(4.249)^{* *}$ & $0.917(11.905)^{* * *}$ & $0.985(3.523)^{* *}$ \\
\hline$\Delta \operatorname{lnMCAP} P_{t-1}$ & $0.022(0.797)$ & - & - \\
\hline$\Delta \ln T U R N O V E R_{t-1}$ & - & $0.020(1.628)$ & - \\
\hline$\Delta \operatorname{lnVALTRD} D_{\mathrm{t}-1}$ & - & - & $0.006(0.496)$ \\
\hline$\Delta \operatorname{lnGFCF}_{\mathrm{t}-1}$ & $0.017(0.143)$ & $-0.052(-0.693)$ & $-0.010(-0.097)$ \\
\hline$\Delta \ln M 3_{t-1}$ & $0.061(0.541)$ & $-0.001(-0.086)$ & $0.082(0.637)$ \\
\hline C & $2.630(0.638)$ & $1.634(1.138)$ & $4.297(1.037)$ \\
\hline
\end{tabular}

Source: Author's Computation using E-views 10; N.B: ** signifies significant at $5 \%$ level

Empirical results show that growth was positively influenced by the first time lag of the three proxies, albeit statistically insignificant at 5\% level. In addition, the long run result reveals that the stability, depth and efficiency effect on growth is lacking. These findings are consistent with empirical studies of (Karim et. al 2017; Okoro G.E; 2016, Sinha et. al; 2015, Haque; 2013; Afolabi, 2015 and Echekoba et. al, 2013). This signifies the need for a proper functioning of the Nigerian stock market to fuel economic growth through capital accumulation and accelerated industrialization. The stock market plays a key role in market-based financial development with asset liquidity, long-run capital adequacy for investment, and efficient use of resources. As a result, a well-functioning stock market remains a crucial indicator of macroeconomic development, attracting long term investment from domestic and foreign investors and thereby playing a key role in accelerating industrialization (Pohoata et. al, 2016; Coskun et. al, 2017.

As for the money supply, empirical findings show that it was positively related to growth in equations 1 and 3 , although statistically insignificant to growth as seen in table 8. This illustrates the fact that the financial sector has little or no innovation that can stimulate money supply while at the same time minimize investment risk in the economy. The findings are reinforced by other empirical studies (Qamruzzanian and Wei, 2017; Bara et. al, 2016; Bara \& Mudzingini, 2016), while gross fixed capital formation shows a positive relationship to growth in equation one only, howbeit, statistically insignificant.

The short run dynamic (ECM_ARDL) model is thus analyzed and described in table 9 based on the confirmed long run relationship.

Table 9. Short-run Dynamic (ECM-ARDL) result

\begin{tabular}{|c|c|c|c|}
\hline & $\begin{array}{c}\text { Equation 1 } \\
\text { ARDL }(1,0,0,1)\end{array}$ & $\begin{array}{c}\text { Equation 2 } \\
\text { ARDL }(1,0,0,1)\end{array}$ & $\begin{array}{c}\text { Equation 3 } \\
\text { ARDL }(1,0,0,1)\end{array}$ \\
\hline$\Delta \operatorname{lnEGWTH} H_{t-1}$ & $1.364(2.553)^{* *}$ & $1.165(3.643)^{* *}$ & $1.463(0.015)^{* *}$ \\
\hline$\Delta \operatorname{lnMCAP}_{\mathrm{t}-1}$ & $0.019(0.717)$ & - & - \\
\hline$\Delta \ln T U R N O V E R_{t-1}$ & - & $-0.003(-0.209)$ & - \\
\hline$\Delta \operatorname{lnVALTRD} \mathbf{t}_{\mathrm{t}-1}$ & - & - & $0.011(0.986)$ \\
\hline$\Delta \operatorname{lnGFCF}_{\mathrm{t}-1}$ & $0.051(0.448)$ & $0.018(0.273)$ & $0.075(0.831)$ \\
\hline$\Delta \mathbf{l n M}_{\mathrm{t}-1}$ & $0.077(0.789)$ & $0.032(0.599)$ & $0.065(0.786)$ \\
\hline $\mathbf{E C T}_{\mathrm{t}-1}$ & $-1.121(-1.899) * * *$ & $-1.001(-2.625)^{* *}$ & $-1.575(-3.628)^{* *}$ \\
\hline \multicolumn{4}{|c|}{ Diagnostic tests } \\
\hline $\mathbf{R}^{2}$ & 0.717 & 0.653 & 0.816 \\
\hline D.W & 1.875 & 2.209 & 2.289 \\
\hline Heteroscedasticity & $0.390(0.537)$ & $0.313(0.580)$ & $1.218(0.279)$ \\
\hline Normality Test & $0.219(0.896)$ & - & $1.389(0.499)$ \\
\hline Reset Test & $0.110(0.746)$ & $0.020(0.886)$ & $0.091(0.768)$ \\
\hline
\end{tabular}

Source: Author's Computation using E-views 10; N.B: ** signifies significant at 5\% level 
The respective speed-of-adjustment to the long run equilibrium is shown in table 9. The result shows that the ECT for each given equation is negative $(-1.121,-1.001$ and -1.575$)$ and statistically significant. This means that any previous period shocks are to be adjusted at speeds of $(112 \%, 100 \%$ and $157 \%)$ respectively in the long run. Furthermore, all indicators except the turnover ratio showed positive effects on growth, howbeit statistically insignificant. This suggests that capital adequacy has not produced the desired economic impact in delivering a significant long run effect for the Nigerian economy. For all three equations, financial innovation (M3) has a positive effect on growth, albeit statistically insignificant. This means that, to some degree, money supply in the economy has supported in recuperating output levels and reduce cost, but has not been successfully in the short-run, but can have long run economic effects. Capital formation showed a positive but marginal effect on growth, indicating theoretically that money supply in the economy, either in the form of capital formation or investment, would stimulate growth by increasing economic activity. Diagnostic tests were performed to assess the validity of the model, including the heterscedasticity test, the test of normality and Ramsey-Reset test (Pagan and Hall (1983). It shows that all statistics are significantly higher than 5 percent, indicating that there is no heteroscedasticity problem and first order serial correlation, usually a desirable indicator of a stable econometric model.

\section{Conclusion and Recommendations}

This study critically investigated the link between stock market development and economic growth in Nigeria for the period, 1985-2018. Reviewed current and existing literature revealed quite a few empirical studies on the subject matters in developed, emerging and developing economies. There have been a number of studies, but a few have been performed on the relationship between stock market development and economic growth has been conducted (Osamwonyi \& Kasimu (2013); Edame et. al (2013); Echekoba et. al. (2013); Okoye \& Nwisienyi (2013) and Ishioro, 2013) among others and a limited number of others focused on stock market-led growth. Seeing the void in existing studies, the study explored a new dimension in stock market development along with financial innovation, where money supply (M3) was used to capture innovation-effect on growth. The study adopted the ARDL Bound test methodology, in order to encapsulate the long run relationship between stock market development and economic growth.

The bounds test demonstrates the existence of a long run relationship for all three (3) models tested. The findings clearly support a long-run relationship between stock-market development and Nigeria's economic growth. In explaining the long- and short run elasticities, findings revealed that stock market development metrics have positive long- and short run impact on economic growth, although insignificantly. This implies that the development of Nigeria's stock market will potentially improve short- and long run growth of the economy by increased depth, stability and efficient financial institutions, capital accumulation and long term capital adequacy. Financial innovation, proxied by M3, had positive impact, albeit statistically insignificant, on economic growth both in the long and short run periods. This shows that stock market financial innovation is expanding financial services by creating new and accelerated institutions, assets and services that eventually lead to accelerated growth.

As far as financial innovation and its effect on growth, innovation is concerned; innovation plays a crucial role in the development of the stock market, as it creates room for the expansion financial activities in the economy by developing new mechanisms and forms of financial institutions. Therefore, policies aimed at making Nigeria's capital market more financially innovation-oriented should therefore be implemented in order to provide large number of households and firms with integrated services, which then can then contribute to the growth cycle.

\section{References}

Adigwe, P. K., Nwanna, \& Ananwude, A. (2015). Stock Market Development and Economic Growth in Nigeria: An empirical examination (1985-2014). Journal of Policy Dev Studies, 9, 134-154.

Afolabi, A. A. (2015). Impact of the Nigerian Capital Market on the Economy, European Journal of Accounting Auditing and Finance Research, 3(2), 88-96.

Altarturi, B. H. M., \& Abduh, M. (2016). Stock Markets and Economic Growth: a comparative analysis between Islamic and conventional markets in Malaysia. Middle East Journal of Management; 3(1), 34-48.

Azam, M., Haseeb, M., Samsi, A. B, \& Raji, J. O. (2016). Stock market development and economic growth: Evidences from Asia-4 countries. International Journal of Economics and Financial Issues, 6(3), 1200-1208.

Babajide, A. A., Lawal, A. I., \& Somoye, R. O. (2016). Stock market response to economic growth and interest rate volatility: evidence from Nigeria. International Journal of Economics and Financial Issues, 6(1), 354-360. 
Bara, A., \& Mudzingiri, C. (2016). Financial innovation and economic growth: Evidence from Zimbabwe. Investment Management and Financial Innovations, 13, 65-75.

Bara, A., Mugano, G., \& Roux, P. (2016). Financial Innovation and Economic Growth in the SADC. Economic Research Southern Africa, 1, 1-23.

Bernard, A. U., \& Austin, A. A. (2012). The role of stock market development in economic growth: A time series analysis. Ethiopian International Multidisciplinary Journal, 6(1), 51-79.

Bilal, L., Chen, S., \& Komal, B. (2016). Impact of stock market development on economic growth: Evidence from lower middle income countries. Management and Administrative Sciences Review, 5(2), 86-97.

Brown, E. D., \& Nyeche, E. W. (2016). The imperative of stock market on economic growth in Nigeria: The endogenous growth model. Business and Economic Journal, 7, 200-218.

Carpenter, J. N., \& Whitelaw, R. F. (2017). The Development of China's Stock Market and Stakes for the Global Economy. Annual Review of Financial Economics, 9, 233-257.

CoSkun, Y., Seven, Ü., Ertugrul, H. M., \& Ulussever, T. (2017). Capital market and economic growth nexus: Evidence from Turkey. Central Bank Review, 17, 19-29.

Deb, S. G., \& Mukherjee, J. (2008). Does Stock Market Development Cause Economic Growth?: Time Series Analysis for Indian Economy. International Research Journal of Finance and Economics, 21, 142-149.

Echekoba, F. N., Ezu, G. K., \& Egbunike, C. F. (2013). The Impact of Capital Market on the Growth of the Nigerian Economy under Democratic Rule. Arabian Journal of Business and Management Review, 3(2), 53-62.

Edame, G. E., \& Okoro, U. (2013). The Impact of Capital Market and Economic Growth in Nigeria. Journal of Public Policy and Administration Research, 3(9), 2-15.

Ezeoha, A., Ogamba, E., \& Onyiuke, N. O. (2009). Stock Market Development and Private Investment Growth in Nigeria. Journal of Sustainable Development in Africa, 11(2), 20-35.

Fynn, K. D. (2012). Does the Equity Market affect Economic Growth?. The Macalester Review, 2(2), 1.

Ghatak, S., \& Siddiki, J. U. (2001). The use of the ARDL approach in estimating virtual exchange rates in India. Journal of Applied Statistics, 28, 573-83.

Hailemariam. A., \& Guotai, C. (2014). Stock market development and economic growth: Empirical evidence for emerging market economies. International Journal of Economics, Finance and Management Sciences, 2(2), 171-181.

Haque, M. E. (2013). Impact of stock market development on economic growth: An evidence from SAARC Countries. International Journal of Research in Commerce, Economics \& Management, 3(1), 15-20.

Hasan, A., \& Raza, M. (2015). Responding to the Transport Crisis in Karachi. IIED-UK Working Paper.

Ho, S. Y., \& Odhiambo, N. M. (2015). Stock market performance in Hong Kong: An exploratory review. Asian Pacific Economic Literature, 29(1), 47-61.

Ikikii, S. M., \& Nzomoi, J. N. (2013). An analysis of the effects of stock market development on economic growth in Kenya. International Journal of Economics and Finance, 5(11), 145-151.

Ishioro, B. O. (2013). Stock Market Development and Economic Growth: Evidence from Zimbabwe. Ekonomska misao i praksa, (2), 343-360.

Jalloh, M. (2015). Does stock market capitalization influences economic growth in Africa?: Evidence from panel data. Applied Economics and Finance, 2(1), 91-101.

Jibril, S. R., Salihi, A. A., Wambai, U. S., Ibrahim, F. B., Muhammad, S., \& Ahmad, T. H. (2015). An Assessment of Nigerian Stock Exchange Market Development to Economic Growth. American International Journal of Social Science, 4(2), 51-58.

Kagochi, J. M., Al Nasser, O. M., \& Kebede, E. (2013). Does financial development hold the key to economic growth? The case of Sub-Saharan Africa. Journal of Developing Areas, 47(2), 61-79. https://doi.org/10.1353/jda.2013.0035

Karim. S., \& Chaudhary, G. M. (2017). Effect of stock market development on economic growth of major South Asian and East Asian economies: A comparative analysis. Journal of Business Studies Quarterly, 8(3), 81-88. 
Khan, M. S., \& Senhadji, A. S. (2000). Financial development and economic growth: An overview. IMF Working Paper No.00/209.

Kolapo, F. T., \& Adaramola, A. O. (2012). The Impact of the Nigerian Capital Market on Economic Growth (1990-2010). International Journal of Developing Societies, 1(1), 11-19.

Levine, R. (1991). Stock Markets, Growth, and Tax Policy. Journal of Finance, 46(4), 1445-65.

Levine, R., \& Zervos, S. (1998). Stock Markets, Banks, and Economic Growth, American Economic Review, 88, 537-558. Retrieved from http://ideas.repec.org/a/aea/aecrev/v88y1998i3p537-53.html

Marinkovic, S., Stojkovic, D., \& Radovic, O. (2013). Stock market development and economic growth (The Case of Belgrade Stock Exchange). Actual Problems of Economics, 143(5), 399-408.

Ndako, U. B. (2009). Stock Markets, Banks and Economic Growth: A time-series evidence from South Africa. Retrieved from http://www/africametrics.org/documents/conferences09/papers/Ndako-pdf

Nyasha, S., \& Odhiambo, N. M. (2015). Banks, stock market development and economic growth in South Africa: A multivariate causal linkage. Applied Economics Letters, 22, 1480-85.

Nyasha, S., \& Odhiambo, N. M. (2016). Banks, Stock Market Development and Economic Growth in Kenya: An Empirical Investigation. Journal of African Business, 18, 1-23.

Odhiambo, N. (2009). Stock Market Development and Economic Growth in South Africa: An ARDL-bounds Testing Approach. Retrieved from http://www.wbiconpro.com/2.Nicholas.pdf

Odo, S. I., Anoke, C. I., Onyeisi, O. S., \& Chukwu, B. C. (2017) Capital market indicators and economic growth in Nigeria: An Autoregrssive Distributed Lag (ARDL) model. Asian Journal of Economics, Business and Accounting, 2(3), 1-16.

Ogunmuyiwa, M. S. (2010). Investor's Sentiments, Stock Market Liquidity and Economic Growth in Nigeria. Journal of Social Sciences, 23(1), 63-67. (Kanla-Raj 2010 Edition). Retrieved from http://www.Krepublishers.com/02-Journals/JSS/JSS-23-0-000-10-web/JSS-23-1-000-10-Abst-PDP/JSS-23-1-06 3-10-780-Ogunmuyiww-m-s-7t.pdf

Ojo, O. M., \& Adeusi, S. O. (2012). Impact of capital market reforms in economic growth: The Nigerian experience. Australian Journal of Business and Management Research, 2(2).

Okonkwo, V. I., Ananwude, A. C., \& Echekoba, F. N. (2015). Nigeria stock market development and economic growth: A time series analysis (1993 - 2013). Scholars J Econ Bus Manage, 2, 280-293.

Okoro, G. E. (2016). Stock market performance and the augmentation of frontier economies: A comparative scrutiny of Nigeria and Mauritius. Studies and Scientific Researches Economics Edition, 23, 13-20.

Okoye, V. O., \& Nwisienyi, K. J. (2013). The Capital Market Contributions towards Economic Growth and Development: The Nigerian Experience. Global Advanced Research Journal of Management and Business Studies, 2(2), 120-125.

Olofin, S. O., \& Afangideh, U. J. (2008). Financial Structure and Economic Growth in Nigeria: A Macroeconometric Approach. Retrieved from http://www.africametrics.org/documents/conference08/day2/sess5.pdf

Ologunwa, O. P., \& Sadibo, O. V. (2016). Capital market development and economic growth in Nigeria: an empirical analysis. FUTA Journal of Management and Technology Maiden Edition, 48-59.

Osakwe, C. I., \& Ananwude, A. (2017). Stock market development and economic growth: A comparative evidence from two emerging economies in Africa-Nigeria and South Africa. Archives Current Res Int, 11, 1-15.

Osamwonyi, I. O., \& Kasimu, A. (2013). Stock market and economic growth in Ghana, Kenya and Nigeria. International Journal of Financial Research, 4(2), 83-98. https://doi.org/10.5430/ijfr.v4n2p83

Ovat, O. O. (2012). Stock Market Development and Economic Growth in Nigeria: Market Size versus Liquidity. Can. Soc. Sci., 8 .

Pagan, A. R., \& Hall, A. D. (1983). Diagnostic tests as residual analysis. Econometric Reviews, 2, 159-218.

Pagano, M. (1993). Financial Markets and Growth: An Overview. European Economic Review, 37, 613-622.

Pan, L., \& Mishra, V. (2018). Stock market development and economic growth: Empirical evidence from China. Economic Modelling, 68, 661-673. 
Pardy, R. (1992). Institutional Reform in Emerging Securities Market. Policy Research Working Papers (Financial Policy and Systems), No. 907, World Bank.

Pesaran, M. H., Shin, Y., \& R.J. Smith. (2001). Bounds testing approaches to the analysis of level relationships. Journal of Applied Econometrics, 16, 289-326

Phillips, P. C. B., \& Perron, P. (1988). Testing for a unit root in time series regression. Biometrika, 75, 335-46.

Pohoată, I., Diaconasu, D. E., \& Socoliuc, O. R. (2016). Economic Dynamics-Stock Market Evolution: A Relation Committed To Dysfunctionality in Romania and Croatia. Ecoforum, 5, 332-37.

Qamruzzaman, M. D., \& Wei, J. (2017). Financial innovation and economic growth in Bangladesh. Financial Innovation, 3, 19.

Ruwaydah, A., \& Ushad, S. A. (2015). Effects of stock market development on economic growth: The case of SADC countries. Proceedings of the Third Middle East Conference on Global Business, Economics, Finance and Banking (ME15 Dubai October Conference), 16-18 October. Paper ID: DF501.

Schumpeter, A. (1912). The Theory of Economic Development: An Inquiry into Profits, Capital, Interest and the Business Cycle. Translated by Redvers Opie. Cambridge. M.A. Havard University Press.

Shittu, I. (2012). Financial Intermediation and Economic Growth in Nigeria. British Journal of Arts and Social Sciences, 4(2), 164-178.

Sinha, A., Joshi, A., Venkataraman, A., Padmanabhan, D., \& Ravi, A. (2015). Analysis of volatility of stock markets in Russia, South Africa, China, Brazil and Argentina. Munich Personal RePEc Archive.

Tang, C. F. (2013). The linkage between stock price and economic growth in Australia: A chicken-and-egg paradox?. Economic Research, 26(2), 99-116.

Wang, B., \& Ajit, D. (2013). Stock market and economic growth in China. Economics Bulletin, 33(1), 95-103. Retrieved from https://ecomod.net/system/files/StockMarket-wang-ajit-ECOMOD.pdf

World Bank. (2019). World Development Indicators, Various Issues to 2019. World Bank: Washington, DC, USA.

\section{Copyrights}

Copyright for this article is retained by the author(s), with first publication rights granted to the journal.

This is an open-access article distributed under the terms and conditions of the Creative Commons Attribution license (http://creativecommons.org/licenses/by/4.0/). 